\title{
ENTRE O POPULISMO CULTURAL E A DISTINÇÃO: Definições do "bem-morar" no Brasil contemporâneo
}

\author{
(1) Carolina Pulici \\ Professora associada do Departamento de Ciências Sociais e do Programa de Pós-Graduação em Ciências Sociais da \\ Universidade Federal de São Paulo (UNIFESP), campus Guarulhos/SP, Brasil. \\ E-mail: carolina.pulici@unifesp.br
}

DOI: 10.1590/3710800/2022

\begin{abstract}
Resumo: Pesquisas sociológicas recentes mostram que, na virada do século $\mathrm{XXI}$, o investimento no espaço doméstico tornou-se ainda mais determinante no posicionamento social dos indivíduos, acompanhando o crescimento de lojas, mostras, prêmios e de uma imprensa de arquitetura e decoração. Mas, enquanto se multiplicam as instâncias de inculcação de gostos domésticos, os repertórios prescritivos do "bem-morar" permanecem pouco estudados na ótica da sociologia. Eis o problema que este artigo propõe explorar, com base nas maneiras de morar validadas por especialistas em luta pela definição dominante da excelência residencial. As regularidades temáticas detectadas por meio de abordagem quantitativa e qualitativa dos esquemas de apreciação inventariados mostram que a detratação de residências supostamente voltadas à "ostentação social" não faz apenas desacreditar certas preferências preconizadas pelo morar "burguês", mas, também, fomentar uma recomposição das lógicas distintivas associadas ao espaço residencial.
\end{abstract}

Palavras-chave: repertórios prescritivos, casa, populismo cultural, distinção, Brasil.

\section{BETWEEN CULTURAL POPULISM AND \\ DISTINCTION: definitions of "welfare" in contemporary Brazil}

\begin{abstract}
Recent sociological research shows that, at the turn of the 21 st century, investment in domestic space has become even more decisive in the social positioning of individuals, following the growth of shops, exhibitions, awards and the press dedicated to architecture and decoration. However, while the instances of inculcation of domestic tastes are multiplying, the prescriptive repertoires of the "art of living" remain little studied from the point of view of sociology. This is the problem this article proposes to explore, based on the ways of living validated by specialists struggling for the dominant definition of residential excellence. The thematic regularities detected by means of a quantitative and qualitative approach to the inventory of appreciation frameworks show that the detraction of the residences supposedly dedicated to "social ostentation" does not only discredit certain preferences advocated by "bourgeois" housing, but also promotes a reconfiguration of the logics of distinction associated with the residential space.
\end{abstract}

Keywords: prescriptive repertoires - house - cultural populism - distinction - Brazil 


\section{Introdução}

Data de antes da eclosão da pandemia da covid-19, no início de 2020, e do longo confinamento doméstico que trouxe consigo, a constatação de que a propriedade de uma casa envolve uma das decisões mais prenhes de consequências durante todo o ciclo de uma vida. No âmbito da sociologia, trabalhos recentes mostram que, nas últimas décadas, o investimento em imóveis residenciais assumiu um papel ainda mais relevante no posicionamento social dos indivíduos. Num contexto de desvalorização dos diplomas, degradação do mercado de trabalho e alta nos preços dos imóveis, principalmente a partir dos anos 2000, vários autores veem no patrimônio imobiliário um socorro aos que enfrentam a ameaça de declínio social (Collet, 2015), um recurso decisivo na reprodução das posições dominantes (Pinçon e PinçonCharlot, 2007)e, mesmo, nas próprias chances de enriquecimento (Boltanski e Esquerre, 2017).

Propriedade que exprime as posses e os gostos de seu possuidor (Bourdieu, 2000; Laferté, 2016), a casa contemporânea também é vista como presa das renovadas normas estéticas (Guedez, 2004) que acompanham o crescimento de lojas, mostras, prêmios e de uma imprensa de arquitetura e decoração (Gilbert, 2016a). Na virada do século XXI, com efeito, os diferentes modos de morar foram crescentemente expostos aos juízos de gosto dos especialistas em arquitetura doméstica (Gilbert, 2016b). Num país como a França, cujos modelos de bem-morar tanto marcaram as aspirações residenciais das elites brasileiras (Homem, 1996; Camargos, 2001; Lemos, 2003; Campos, 2005), as estatísticas do Ministério da Cultura mostram que o número de revistas da categoria Maison et Décoration mais do que dobrou, passando de 36 em 1995 a 88 em 2005 e a 105 em 2010. A difusão total, por sua vez, passou de 37,4 milhões de exemplares em 1995 a 46,2 milhões em 2005 e a 47,8 milhões em 2010. ${ }^{1}$

Resguardadas as diferenças entre os países, o Brasil também registrou um aumento súbito de publicações que se atribuem a tarefa de promover o refinamento de diferentes áreas do espaço residencial, confirmando estudos transnacionais que detectaram uma proliferação de guias de sofisticação cultural na contemporaneidade (Lamont, 1992). A esse respeito, um levantamento dos títulos de periódicos registrados no catálogo da Biblioteca Nacional sugere ainda que as aceleradas transformações que marcaram a virada do século XXI, com a incorporação das técnicas de impressão digital e o barateamento relativo do preço do papel, também contribuíram para a presença simultânea de dois fenômenos, à primeira vista, contraditórios: a rotinização da internet e o crescimento significativo da imprensa escrita dedicada à casa. Assim, a busca de publicações periódicas impressas em português no âmbito do assunto "casa" - e de 51 subtemas - traz um total de 295 resultados. Restringindose a busca aos subtemas "decoração de interiores", "arquitetura de interiores", "arquitetura de habitação", "arquitetura de habitação - projetos e plantas" e "arquitetura", obtém-se um total de 261 ocorrências, das quais 216 foram publicadas a partir de $2000 .^{2}$

A intensificação do trabalho de inculcação de gostos domésticos também se exprime no aumento do público da CASACOR São Paulo, a mais importante mostra de arquitetura e decoração no Brasil que, tal como os salões do mundo do vinho na França contemporânea, equivale às bienais de arte para os artistas e assume o papel de uma "Academia" (GarciaParpet, 2004, p. 81). Se a edição de 2000 registrou a presença de "mais de 53 mil pessoas", em 2005 contabilizou-se "mais de 80 mil visitantes" e, em 2009, "mais de 140 mil pessoas". 3 A mesma fonte desses números aponta para a profissionalização do universo prescritivo que, ainda no final do século XX, atuava como instância de consagração dos gostos das elites, como não nega o fato de que a própria CASACOR surge, em 1987, como um evento social e caritativo promovido por senhoras da alta sociedade do Jardim Europa, ${ }^{4}$ um dos bairros

\footnotetext{
Fonte: http://www.culture.gouv.fr/Thematiques/Presse/Chiffres-Statistiques (consultado em 15/07/2019).

Foram excluídas desta contagem duas ocorrências cujas datas de publicação não foram informadas.

Fonte: https://casacor.abril.com.br/historia/ (consultado em 15/08/2020).

4 "No dia 8 de junho de 1987, o número 81 da rua Dinamarca, no Jardim Europa, em São Paulo, abriu as portas para o público da primeira CASACOR. Idealizada por Yolanda Figueiredo e Angélica Rueda, a mostra surgiu
} 
mais exclusivos da cidade de São Paulo; ou ainda o testemunho de um pioneiro do design brasileiro para quem "as fotos de decoração eram feitas nas casas mais arrumadas da cidade, onde as próprias donas transavam o seu ambiente"(Mira, 2013, p. 52).

Mas, enquanto se multiplicam os suportes prescritivos do "bem-morar", 5 os critérios de apreciação validados pelos que difundem as preferências que são possíveis, num dado momento, em matéria de moradia permanecem pouco estudados na ótica da sociologia. Eis o problema que este artigo propõe explorar, centrando foco nas lógicas distintivas subjacentes às definições dominantes da excelência residencial. Na interface dos trabalhos dedicados à produção da arquitetura residencial (Wolff, 2001), de um lado, e daqueles centrados em sua recepção pelos moradores (Denèfle et al., 2006), de outro, o estudo das "boas maneiras de morar" direciona-se às categorias de percepção inculcadas pelas instâncias intermediárias (Lizé et al., 2011) entre a oferta e a demanda. Dentre os propagadores de recomendações em matéria de arranjo doméstico, a imprensa de arquitetura e decoração figura como um dos principais vetores da legitimação de preferências, assumindo papel-chave no ajuste entre a produção e a recepção residencial (Chevalier et al., 2013, p. 104), na validação das normas previamente definidas pelos profissionais da arquitetura doméstica (Tapie, 2018), na valorização dos antigos bairros populares gentrificados (Collet, 2015, p. 158) e, ainda, no enaltecimento de patrimônios imobiliários associados a um território nacional, produzindo narrativas que certificarão sua dimensão ancestral e justificarão seus preços exorbitantes (Boltanski e Esquerre, 2017, p. 444). Considerando-se que, além de cumprirem "um trabalho de educação do gosto", tais publicações também "favorecem a propaganda de produtos e serviços consumidos pelo mesmo segmento de público"(Durand, 1989, p. 179), não surpreende que o setor "Casa e Decoração" tenha ocupado, no contexto brasileiro relativo ao ano de 2015, a terceira colocação na lista dos dez setores com maior investimento publicitário em revista. ${ }^{6}$

Assim, na trilha de pesquisas sociológicas recentes que escrutinaram revistas sobre estilos de vida, especialidade relegada em prol de temáticas tidas como mais relevantes (Naulin, 2017), prolongamos o esforço dos que veem tais publicações como instâncias de consagração de gostos e de visões de mundo (Johnston e Baumann, 2007). Em continuidade a uma investigação comparativa em curso sobre a gênese social do gosto arquitetônico no Brasil e na França nos primeiros 15 anos do século XXI (Pulici, 2020), esta análise dos princípios de hierarquização subentendidos nos modos de morar legitimados no contexto brasileiro se baseia, principalmente, no tratamento qualitativo e quantitativo do repertório prescritivo veiculado pela revista Casa e Jardim. O exame das categorias de apreciação preconizadas pelo título mais antigo e de maior circulação no segmento permite lançar a hipótese de que o enaltecimento de residências supostamente avessas à "ostentação social" - por meio de referenciais a um só tempo populistas e elitistas - não faz apenas desacreditar as preferências que mais automaticamente evocam o morar "burguês", mas, também, fomentar uma recomposição das lógicas distintivas associadas ao espaço residencial. Como esperamos conseguir demonstrar ao final deste artigo, tal recomposição faz, sobretudo, atualizar os processos de inclusão e exclusão que têm por critério de base a intolerância estética, mediante o enobrecimento de partidos arquitetônico-decorativos igualmente excludentes, mas desta vez em benefício dos moradores de casas tidas por "despojadas" e "despretensiosas" que logram, assim, acumular todas as vantagens possíveis, tanto as creditadas ao progressismo político quanto as atribuídas ao vanguardismo cultural.

com o intuito de ser um evento social, cultural e benemérito [...]. Parte da renda arrecadada foi destinada para a Associação Obra do Berço, iniciando o compromisso social da marca".

Sobre os atuais programas de TV, o Discovery Home \& Health informou que "entre os dez shows de maior audiência do canal em 2020, sete são do gênero de Casa \& Decoração. Só este ano, os programas com essa temática foram sintonizados por mais de 12 milhões de pessoas diferentes no canal" (Lourenço, 2020, p. H5).

6 A força do meio revista, relatório da Associação Nacional dos Editores de Revista para o ano de 2015. Fonte: https://aner.org.br/wp-institucional/wp-content/uploads/2015/06/Factbook_2015.pdf(consultado em 12/06/2020). 


\section{Fontes e metodologia}

Este artigo se baseia no levantamento exaustivo dos exemplares de Casa e Jardim publicados entre 2000 e 2015 ( $n=192)$. Homóloga brasileira da igualmente decana Art et Décoration, examinada previamente no contexto francês, Casa e Jardim foi lançada em 1953, 20 anos antes de Casa Cláudia (1973), 22 anos antes de Casa Vogue(1975) e 35 anos antes de Arquitetura e Construção (1988). Também como sua correspondente francesa, Casa e Jardimé a revista mais vendida no domínio da arquitetura e da decoração atualmente no Brasil. Em vista disso, a totalidade das capas, dos sumários e dos editoriais constituem o corpus principal do presente texto, submetido à mesma análise serial, temática e quantificada realizada previamente com as revistas francesas.

Dentre os vários livros publicados no período de referência da pesquisa, os "guias do bem-morar" mobilizados neste artigo são: Casas de São Paulo (2009), de autoria da crítica de decoração e embaixatriz brasileira Maria Ignez Barbosa, e Casas do Brasi/(Quintas et al., 2013), lançado pela revista Casa e Jardim. A pesquisa documental é complementada por observações e coleta de materiais em duas edições da CASACOR São Paulo (as de 2018 e 2019 realizadas no Jockey Club), em uma edição da CASACOR Rio de Janeiro (a de 2019 realizada no Edifício Touring) e nas mostras Modernos Eternos (no Mosteiro de São Bento) e Morar Mais (em dois casarões de Alto de Pinheiros), ocorridas em 2019 em São Paulo. Também foram realizadas uma entrevista com a antiga diretora de redação de Casa e Jardim e outra com a atual presidente da Associação Brasileira de Designers de Interiores.

\section{Casa e Jardim no espaço das revistas dedicadas à casa}

Publicação periódica brasileira mais antiga em circulação até os dias atuais e a primeira dedicada à arquitetura doméstica, Casa e Jardim foi criada pelo editor e industrial gráfico Carlos Oscar Reichenbach (1907-1960) em 1953, momento de celebração mundial da arquitetura brasileira. A revista então publicada pela Editora Monumento atribui-se, em seu primeiro editorial, a tarefa de "divulgar, dentro de nossas próprias fronteiras, as realizações de nossos arquitetos de casas e jardins, já tão conhecidas no exterior", que não apenas criaram "uma arquitetura peculiar brasileira, como ainda conquistaram uma alta reputação além-fronteiras, dando à arquitetura brasileira um sólido conceito" (Reichenbach, 1953, pp. 6 e 7). Revista que nasce, portanto, para divulgar o gosto modernista dos anos 1950 (Lemos, 2003, pp. 92-97), Casa e Jardim celebra sua antiguidade sem par na capa de cada exemplar, como ocorreu nas doze edições de 2018, mesmo ano em que o Instituto Verificador da Comunicação registrou ser esta a revista de arquitetura e decoração de maior circulação no país, conforme tabela 1.

TABELA 1 - Circulação (impressa e digital) dos cinco títulos filiados ao IVC no $1^{\circ}$ semestre de 2018

\begin{tabular}{l|c|c|c|c}
\hline \multicolumn{1}{c|}{ Título } & $\begin{array}{c}\text { Ano de } \\
\text { criação }\end{array}$ & Circulação & $\begin{array}{c}\text { Grupo } \\
\text { empresarial }\end{array}$ & Sede \\
\hline Casa e Jardim & 1953 & 112.290 & Editora Globo & Jardim Paulista \\
\hline Casa Vogue & 1975 & 25.108 & $\begin{array}{c}\text { Globo-Condé } \\
\text { Nast }\end{array}$ & Jardim Paulista \\
\hline Casa Cláudia & 1977 & 95.490 & Editora Abril & Vila Arcádia \\
\hline Arquitetura e Construção & 1988 & 55.474 & Editora Abril & Vila Arcádia \\
\hline Minha Casa & 2010 & 82.161 & Editora Abril & Vila Arcádia \\
\hline
\end{tabular}

Fonte: elaboração própria a partir dos dados do IVC e de mídia kits das editoras Globo e Abril. 
Com a única exceção da revista Minha Casa, criada em 2010 e direcionada ao grupo que se convencionou chamar de "nova classe média" no Brasil dos anos 2000 (Ishiki, 2017), todas as demais revistas repertoriadas pelo IVC miravam um público que, em sua esmagadora maioria, pertencia às classes que o mundo do marketing chama de "A e $\mathrm{B}^{\prime \prime}$, registravam a difusão mais significativa, pertenciam aos grandes conglomerados de imprensa (Abril, Globo) e figuravam como os periódicos mais antigos do mercado no período coberto pela pesquisa. Num universo formado por dezenas de revistas que desaparecem ser deixar vestígios, a antiguidade é um fator distintivo dos títulos que atravessam os anos enquanto até mesmo aqueles que gozaram de grande prestígio durante várias décadas acabam por desaparecer, como foi o caso de Casa Cláudia, por muito tempo a revista mais vendida nesse segmento, mas, também, de Arquitetura e Construção e de Minha Casa, três títulos da Editora Abril que saíram de circulação a partir do $2^{\circ}$ semestre de 2018, no bojo da crise que levou o grupo Abril a pedir recuperação judicial, pôr fim a muitas de suas revistas e mudar o local da redação.

Assim, ao iniciarmos a pesquisa de campo no contexto brasileiro, em 2018, a principal concorrente de Casa e Jardim, o título em relação ao qual sempre se mediu, Casa Cláudia, publicaria seu último exemplar em agosto do mesmo ano. Nesse cenário de crise de toda a imprensa escrita, a dependência das revistas em relação à saúde financeira de seus grupos mantenedores foi, não por acaso, uma das principais razões apontadas pela antiga redatora-chefe de Casa e Jardim em resposta à pergunta referente à longevidade excepcional do título. Considerando-se o custo elevado, segundo ela, de produção de uma revista como a que dirigiu por oito dos 20 anos em que trabalhou para a publicação, o peso da Editora Globo foi e continua sendo determinante, pois se tivesse continuado na editora pequena em que esteve entre 1965 e 1997, a Efece, possivelmente teria desaparecido: "porque não é a banca que sustenta a revista", 7 mas a publicidade anunciada em suas páginas, negociada por um departamento comercial forte para garantir a circulação dos periódicos da empresa. Para ela, cada uma das cinco principais revistas do segmento em circulação entre 2000 e 2015 logrou alcançar uma identidade própria e, consequentemente, pouca sobreposição de público leitor, o que se aplica principalmente a Casa Vogue, a Arquitetura e Construção e a Minha Casa. Derivada da Vogue, marca de licença internacional publicada em 22 países diferentes, Casa Vogue sempre teria se dirigido a um público mais restrito e elitizado ( "bem pequeno, mas bem fiel'), especializado em design e ávido de informações sobre novos produtos estrangeiros e seus locais de compra no exterior. Embora a mudança introduzida na linha editorial de Casa e Jardim no sentido de dar mais protagonismo ao morador - ponto de inflexão de que trataremos adiante - tenha resultado numa proporção de leitores "classe A" ainda maior do que a de Casa Vogue - como se vê na tabela 3 adiante -, com pequena sobreposição de público ("Nem todo mundo que é classe A é do estilo Casa Vogue"), por ora cabe reter que o título de licença internacional editado pela Condé Nast em parceria com a Globo ocupava historicamente o polo mais exclusivamente vinculado ao leitor de elite - como na tabela 2 a seguir. ${ }^{8}$

TABELA 2 - Propriedades sociais do público leitor da revista impressa em 2019

\begin{tabular}{c|c|c|c|c|c|c}
\hline \multicolumn{1}{c|}{ Título } & Circulação & Leitores & $\begin{array}{c}\text { Classe } \\
\text { AB }\end{array}$ & Mulheres & $\begin{array}{c}\text { Distribuição } \\
\text { geográfica }\end{array}$ & $\begin{array}{c}\text { Faixa } \\
\text { etária }\end{array}$ \\
\hline Casa e Jardim & 104.735 & 842.000 & $66 \%$ & $78 \%$ & $59 \%$ região Sudeste & $28 \% 55+$ \\
\hline Casa Vogue & 19.403 & 266.000 & $77 \%$ & $85 \%$ & $?$ & $31 \% 25-34$ \\
\hline
\end{tabular}

Fonte: elaboração própria a partir dos dados dos mídia kits da editora Globo relativos ao ano de $2019 .{ }^{9}$

\footnotetext{
7 Entrevista realizada por teleconferência em 29/07/2020, com a ciência de sua divulgação para fins acadêmicos.

8 A partir de 2010 a edição da Casa Vogue brasileira, que desde 1975 era dirigida pelo Grupo Carta, passa a ser controlada pela joint venture do grupo americano Condé Nast com a editora Globo.

9 A porcentagem relativa à distribuição geográfica dos leitores foi extraída do mídia kit da editora Globo concernente ao ano de 2015, por estar ausente dos materiais publicitários produzidos posteriormente.
} 
TABELA 3 - Pertencimento social dos leitores do conteúdo digital

\begin{tabular}{c|c|c|c}
\hline Título & Classe AB & Mulheres & Faixa etária \\
\hline Casa e Jardim & $88 \%$ & $69 \%$ & $47 \% 25-34$ \\
\hline Casa Vogue & $71 \%$ & $80 \%$ & $25 \% 25-34$ \\
\hline
\end{tabular}

Fonte: elaboração própria com base nos dados disponíveis em: https://www.

publicidadeeditoraglobo.com.br/casavogue (consultado em 11/06/2020).

No polo oposto ao de Casa Vogue em termos de recrutamento social do público leitor, Minha Casa apresenta a que veio no slogan "Decoração, reforma e construção ao seu alcance", condizente com a parcela de $79 \%$ de seus 825.000 leitores (em 2016) situada nas "classes B e C". ${ }^{10}$ Para a antiga redatora-chefe de Casa e Jardim, Minha Casa fora "um fenômeno de banca" ("porque eles eram bem populares") que teria fracassado em termos de anúncio: "Porque você tem um mercado que não é popular, então por mais que eles usassem móveis e coisas mais populares nas produções [...] não tinham talvez o ganho de publicidade que é o que sustenta", remetendo ao desinteresse dos anunciantes de luxo pela imprensa dirigida a um público de menor poder aquisitivo. No seu entender, Casa Vogue e Minha Casa nunca foram concorrentes diretas de Casa e Jardim, nem tampouco Arquitetura e Construção, que por mais de 30 anos teria sido fonte de consulta numa fase específica da vida de seus leitores: a da construção ou reforma de uma casa, conforme seu slogan "a revista para construir ou reformar sua casa".

Desse modo, a verdadeira concorrente de Casa e Jardim sempre fora Casa Cláudia, revista do grupo Abril da qual logrou, ao fim e ao cabo, se desprender. Diferentemente de Casa e Jardim, criada em 1953 para ser a primeira revista de arquitetura e decoração do país, Casa Cláudia foi lançada em 1977 como magazine derivado da revista-mãe Cláudia que, por seu turno, apresentava a particularidade de ser "o abrasileiramento de uma fórmula de revista feminina mensal que já vinha sendo aplicada, fazia vários anos, nos EUA (Mc Call's e Ladies Home Journal) e na Europa (Marie Claire, Arianna)" (Mira, 2013, p. 51). Ainda assim, ambas seriam revistas de decoração mais do que de arquitetura (diferentemente de Arquitetura e Construção), dirigindo-se tanto uma quanto a outra a um público de classe média-alta para cima (diferentemente de Minha Casa), com um conteúdo mais generalista e menos especializado (diferentemente de Casa Vogue). Para essa informante, que ocupava o posto de redatora-chefe de Casa e Jardim quando a redação implementou mudanças que teriam permitido ao título deixar de ficar "sempre um passo atrás de Casa Cláudia", esse divisor de águas corresponde ao momento em que a revista começou a procurar "casas de verdade, porque as casas eram todas iguais, elas eram perfeitas, to das beges, não tinha nada fora do lugar". Nesse contexto, a coluna Decoração pelo mundo, por exemplo, fora criada para sustentar tal decisão, uma vez que na Europa existiriam mais "casas de verdade" do que no Brasil (até porque, como reconhece, todas têm "móveis de família" e seu entorno - bairro, cidade - já é muito ordenado e arrumado). Essa procura por casas que não fossem em tudo impecáveis vinculou-se a um segundo partido que passou a ser sistematicamente adotado com o fito de se descolar de sua concorrente mais direta, e que consistiu em dar ênfase à história do habitante. ${ }^{11}$ Assim, ao invés de continuar "numa coisa bem técnica" ("essa casa de $500 \mathrm{~m}^{2}$ no bairro de Pinheiros"), começaram a "mudar o texto, a gente começou a colocar o morador como protagonista da história [...] A gente também sofreu muito 'preconceito' porque o arquiteto/o decorador deixou de ser o protagonista".

Num percurso exemplar daquilo que a história social da arquitetura chama de "populismo" (Wright, 1980) e que corresponde, grosso modo, à participação direta do habitante na produção arquitetônica, como se este pudesse, tanto quanto o arquiteto,

\footnotetext{
${ }^{10}$ Disponível em: http://publiabril.abril.com.br/marcas/minha-casa/plataformas/revista-impressa (consultado em 20/06/2020).

11 Sobre o histórico dessa concorrência, cabe lembrar ainda que com a recessão econômica de 1979 a 1984 "só Casa Cláudia e Casa e Jardim permaneciam em circulação, atingindo conjuntamente um público leitor próximo a 1,1 milhão de pessoas" (Durand, 1989, p. 286).
} 
chegar até mesmo a assumir a prancheta (Cohen, 2004), a redação se agarra ao suposto de que o modo de ser do morador era o que "compunha a história toda". No retrospecto da informante, foi "todo um outro processo"fazer os moradores aparecerem, porque "não eram modelos, nem todo mundo era bonito". Malgrado tais dificuldades,

o mercado foi entendendo que a casa estava caminhando para isso, né, que aquela casa intocável não fazia mais sentido... Mas, no começo, foi difícil, resistência do mercado e da editora mesmo porque houve um momento de queda, o público mais elitizado sentiu um incômodo diante de algo mais despojado.

Assim, ao entrar mais explicitamente na vida dos habitantes, a revista teria crescido, criado nova identidade e finalmente ultrapassado Casa Cláudia ("As pessoas se viram ali de verdade, foi onde a gente acabou crescendo bastante'). Embora, como se verá adiante, a análise serial da totalidade dos números publicados entre 2000 e 2015 não confirme essa visão de que Casa e Jardim teria passado a mostrar "aquela casa que era a casa que todo mundo tinha" - uma vez que os ambientes domésticos propostos vão sendo cada vez menos acessíveis a um público leitor que não seja rico -, cabe reter, neste estágio, que o ponto de inflexão autoatribuído pela revista (e, de certo modo, realizado) correspondeu bastante bem ao "populismo estético" (Ferrari, 2015) associado à virada do século XXI. Tanto assim que o partido de se prender aos climas de opinião do momento via valorização crescente das supostas imperfeições das "casas de verdade" Ihe permitiu honrar as pressões democratizantes da contemporaneidade e, a um só tempo, glorificar espaços residenciais ainda mais excepcionais.

\section{A complacência populista}

Considerando-se o que foi dito até aqui, não surpreende que, a partir de 2008, os moradores apareçam em cada nova capa de Casa e Jardim, o que não acontecia com a mesma sistematicidade nas capas de Casa Cláudia e também não acontece nas de Casa Vogue, como se vê nas imagens abaixo (Figura 1). Outro indício dessa orientação é o slogan "Sua casa linda do seu jeito", que passa a figurar na lombada da revista desde 2010, justamente no período de maior elitização, como veremos.
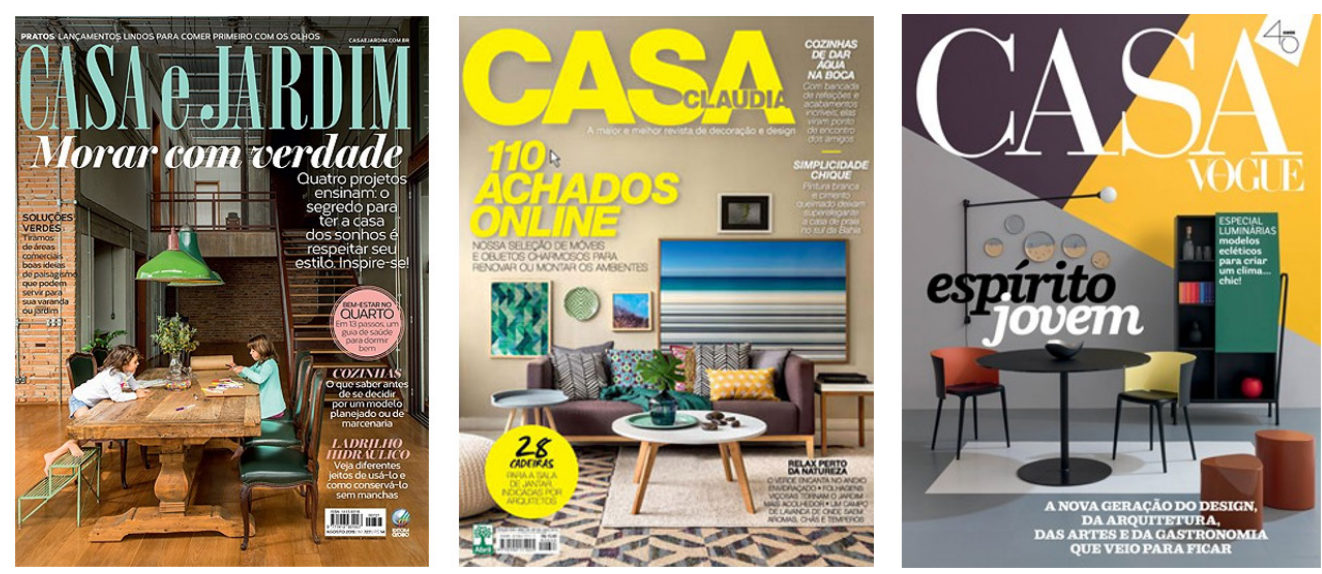

Figura 1 - Capas de agosto de 2015: Casa e Jardim, Casa Cláudia e Casa Vogue / Fonte: websites das revistas ${ }^{12}$

Condizente com esse posicionamento editorial é também a apresentação (desde 2008) do quadro "Nossos Valores", cujo subtítulo é "Casa e Jardim deixa a casa com a sua cara".

\footnotetext{
12 https://revistacasaejardim.globo.com/noticia/2015/08/casa-e-jardim-de-agosto-edicao-727.html; https://
} images.app.goo.gl/QMoYyJDV6yycvaj97; https://casavogue.globo.com/Capas/noticia/2015/08/espirito-jovem- 
Outro não é o partido que o título se atribui no mídia kit de 2019, pois sintetiza algumas das principais estratégias discursivas identificadas na análise de conteúdo, quais sejam: "projetos com personalidade" e "ambientes únicos e repletos de boas histórias". Além da defesa de "uma decoração plural, sem certo ou errado", a visão da revista sobre si mesma aponta como outro "diferencial" o fato de ser "a única publicação que ressalta a brasilidade e os regionalismos que tornam o Brasil tão plural [...], mas também mantém seu radar em tendências internacionais". O editorial do n 644 ( "Viva a diferença") é ainda mais explícito na afirmação de que "os anos 2000 serão marcados pela democracia na decoração" e de que é cada vez mais corrente "encontrar projetos de interiores que exibam o histórico e os gostos pessoais dos moradores"(Quintas, 2008a, p. 4). Vários outros exemplares do mesmo ano têm como palavra de ordem, seja na chamada principal da capa, seja nas matérias de capa, títulos como "Deixe a casa com o seu jeito" e/ou "Minha casa tem a minha cara".13

Afora a presença de temas historicamente recorrentes nas revistas dedicadas à casa, como o dos benefícios restauradores de um espaço doméstico acolhedor - haja vista a coluna "Ninho", propagadora da "visão nidificadora do lar" (Carvalho, 2008, p. 283) -, a "complacência populista" (Bourdieu, 2007, p. 371) que atribui ao morador a maior competência em matéria de arquitetura doméstica torna-se onipresente nos exemplares da revista, com edições que trazem mais de uma matéria centrada nessa temática, como dá a ver o sumário do número 662 (p. 10), que apresenta as matérias "Pessoal e intransferível", consagradora da casa sob medida cujos ambientes refletem o morador, e "Casa ao seu modo", que estimula os leitores a quebrarem regras. A ode à originalidade pessoal se prolonga no sumário do número 663 (p. 10), que segue recomendando os arranjos que deem "personalidade à ambientação". Referindo-se à Semana de Design de Milão, "o evento mais aguardado pelo mundo da decoração", o editorial do número 664 se apoia nessa que é uma das maiores cauções culturais do título para defender a "quebra de padrões" (Quintas, 2010b) e sublinhar que as tendências internacionais estariam a respaldar a unicidade da decoração que é fiel ao gosto do morador. Carregada de "sentimentalismo populista" (Bourdieu, 2007, p. 45), a representação do habitante como autoridade-mor no quesito interior doméstico também figura no editorial "Sim, você pode (e deve)" (Quintas, 2009a, p. 8). No contexto de uma discussão sobre os "micos da decoração", pauta sugerida pelos leitores, a diretora de redação afirma que "na decoração, tudo pode"(p. 8), no que é secundada, no sumário do mesmo exemplar, pela exortação: "Esqueça o 'não pode.' Depende de como é usado e, sobretudo, do estilo do morador" (p. 10). Outro não é o diapasão do editorial "A sua casa é (ou deveria ser) o que você é" (Quintas, 2009b, p. 8), plaidoyer para que os arquitetos respeitem o gosto do morador. Vê-se o mesmo no número 657, cujo tema principal da capa é "Decoração à sua moda" e cujo editorial afirma que hoje a tendência "é a de ser fiel a você até mesmo na decoração"(Quintas, 2009c, p. 8).

Os conselhos legitimadores da expressão "pessoal" na arquitetura residencial deitam raízes nos escritos sobre o bem-morar. Em Moralism and the Model Home, Gwendolyn Wright discute as revistas e guias da vida doméstica da Chicago de fins do XIX enquanto "populist visions", não apenas por enaltecerem interiores que carregassem as marcas de seus moradores, mas também por estarem mais sintonizadas com as aspirações das classes médias do que com o arquiteto suspeito de projetar apenas para as elites. Mas, se neste contexto "as escolhas refletiriam a individualidade dos habitantes e o vigor do espírito criativo nacional" (Wright, 1980, p. 23), ${ }^{14}$ pode-se dizer que, em Casa e Jardim, essa individualidade é bastante relativa, pois, enquanto o sumário do número 666 elenca

em-todas-frentes.html (consultado em 13/04/2020).

${ }^{13}$ Capa, editorial e sumário da edição 647, 2008: 6 e 8.

${ }^{14}$ Trecho traduzido por nós, assim como todas as citações subsequentes de textos em língua francesa e inglesa. 
bons motivos para que se conceba uma casa como "retrato do que você é", o do número 665 apresenta uma matéria sobre "portas com um quê a mais" referindo-se a modelos "prontos para copiar"; se o sumário do número 717 enaltece as cozinhas planejadas que "esbanjam personalidade", a edição anterior recomenda - já no título de uma matéria sobre como Dinamarca, China e Paris inspiram decorações inovadoras - que o leitor "copie o visual". Assim, muito embora a louvação de decorações "únicas" atravesse a totalidade dos exemplares analisados, o editorial do número 660 apresenta a criação da coluna Decoração pelo mundo, cujas "ideias podem ser reproduzidas onde quer que você more" (Quintas, 2010a, p. 8).

Também a ideia de que as "casas de arquiteto" parecem "símbolos inadequados de domesticidade para a cidade como um todo" (Wright, 1980, p. 16) não é estranha aos posicionamentos de Casa e Jardim, sobretudo na fase em que, paradoxalmente, divulga de forma mais recorrente residências de exceção feitas por célebres arquitetos contemporâneos. Tal contradição se dá bem a ver nas ocasiões em que apresenta, num mesmo sumário, um casebre em Goiás sob a rubrica "Casas do Brasil" logo abaixo de um casarão de inspiração modernista; ou então uma modesta casa do interior do Mato Grosso do Sul imediatamente abaixo de uma mansão cujo jardim exigiu a junção de dois terrenos inteiros (Figura 2) ou, enfim, quando cria, em meados de 2009, uma seção exclusivamente destinada a retratar tais casebres.

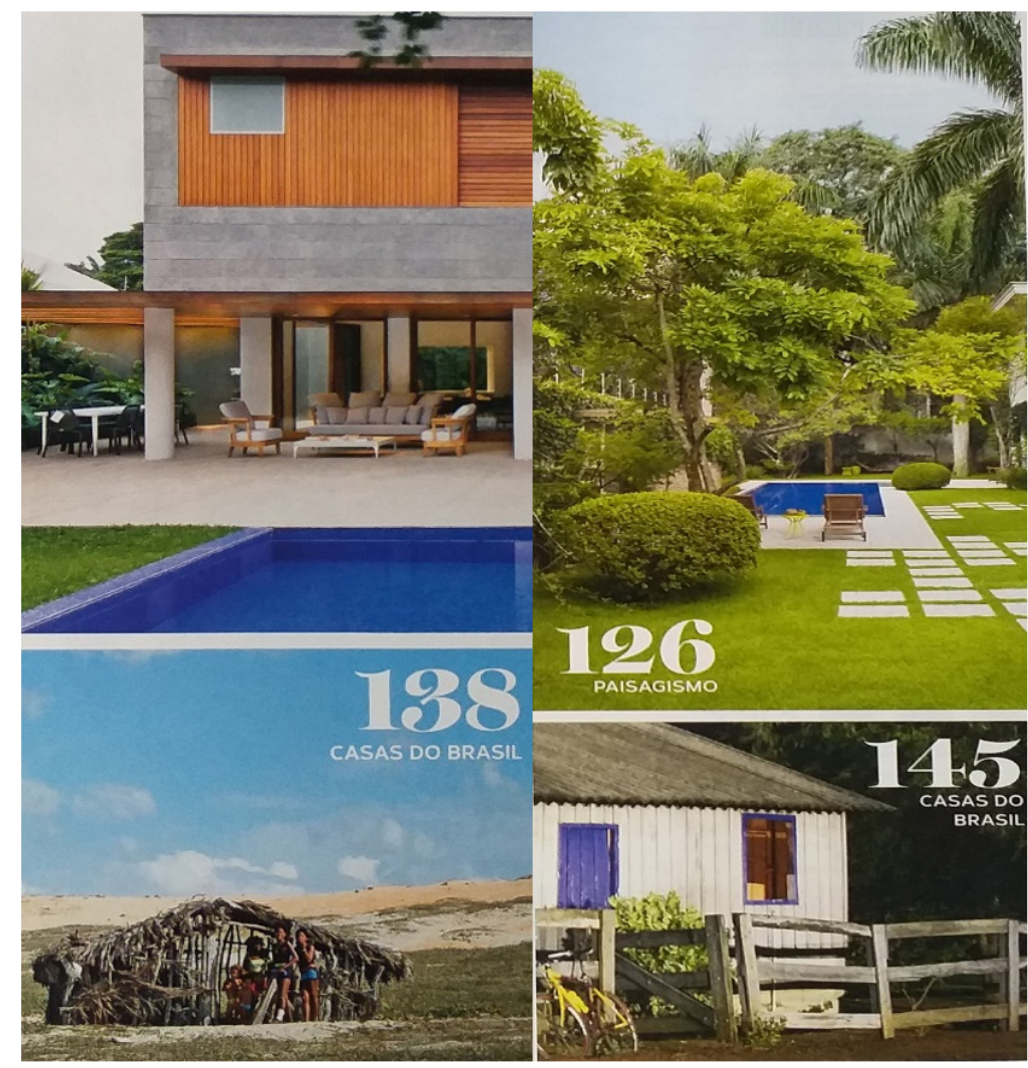

Figura 2 - Populismo e distinção nos sumários de Casa e Jardim | Fonte: Casa e Jardim $(2013 \text {, n. } 703 \text {, p. } 23 ; 2014 \text {, n. } 710 \text {, p. } 21)^{15}$

Publicado em 2013, quando "a revista mais antiga sobre decoração em circulação no país completa 60 anos", o livro Casas do Brasil (Quintas et al., 2013) reúne as matérias da seção supracitada e, como as fotografias do pitoresco social, "coloca à distância as classes

\footnotetext{
${ }^{15}$ Acervo próprio.
} 
populares constituindo-as como objeto de contemplação", fornecendo "uma oportunidade de experimentar a relação da proximidade distante, sob a forma da desrealização operada pelo realismo estético e pela nostalgia populista"(Bourdieu, 2007, p. 59-60).

A começar pela apresentação que agradece aos "fotógrafos renomados" que ajudaram a contar, "de forma despretensiosa", a história da arquitetura e da decoração brasileiras, seguindo no diapasão de incontáveis editoriais ao sugerir que casas "genuínas" são as que carregam a história dos moradores, sejam elas "simples" ou "sofisticadas" (Quintas, 2013, p. 11). A complacência populista que atribui ao povo brasileiro a maior criatividade em matéria de moradia, seja "uma casa pequena[ou] um apartamento grande", escancara-se na propaganda de página inteira da Italínea móveis, ${ }^{16}$ patrocinadora principal da publicação.

Mas é igualmente explícita nos relatos dos fotógrafos junto às fotos realizadas em todas as regiões do país. Em Tocantins, diz-se: "Dona Diva, doceira de mão-cheia e chefe de família, nos brindou com um suco inesquecível de cajá. Sua casa simples é organizada. O filtro (com capa de tricô da vovó) sobre o móvel, feito pelo marido e pelos filhos dela, fica na varanda para facilitar os passantes. Tudo simétrico!" (Quintas et al., 2013, p. 27). Sobre uma casa na llha de Marajó: "o amor e o cuidado com os objetos e os móveis sintetizavam tudo, tudo o que a decoração deve ser. Lembrança, afeto, cuidado, conforto. As toalhas de renda, os troféus da familia, São Jorge e os gatinhos de porcelana - plena harmonia decorativa na Ilha de Marajó(p. 28). Em "Formalismo caboclo" assim se resumem as edificações de uma comunidade de Rondônia: "Nas construções, ripas e tábuas são geometricamente agrupadas, cores fortes e tons pastel se alternam e se completam. Em um lugar distante das facilidades e do luxo, me surpreendeu o cuidado com a forma de morar. A arquitetura cabocla me fascina"(p. 36).

Atento às "linhas sedutoras" de uma casa fotografada no interior do Mato Grosso do Sul, outro fotógrafo acrescenta: "não só as linhas externas me seduzem, mas também o interior desses espaços e até mesmo seus habitantes e usuários" (p. 60). Realizada em Cuiabá, a foto de Cristiano Mascaro exalta "corredores como este, elegantíssimo na sua simplicidade" (p. 64). Reverenciando "a sabedoria popular[que] está expressa nas casas de taipa"(p. 66), outra profissional vê sua fotografia realizada em Goiás como testemunho da arquitetura vernacular e "dos desenhos que a luz faz nos espaços internos das casas populares". Outro fotógrafo avalia que seu retrato de Parintins (Amazonas) "reproduz a síntese da pureza e do poder de um povo que sabe viver de um modo simples, porém autêntico"(p. 34).

Os valores da "autenticidade" são igualmente reverenciados na mostra Morar Mais, cujo slogan "O chique que cabe no seu bolso"(Figura 3) também remete à visão populista de que não se deve considerar apenas as aspirações residenciais das elites historicamente priorizadas pelo profissional de arquitetura. Com o bordão "morar mais por menos é autêntico", as idealizadoras da feira criada em 2004 abrem o anuário da $16^{a}$ exposição reiterando palavras de ordem recorrentes nas páginas de Casa e Jardim, como as variações em torno da prescrição antiprescritiva ("chique é ser fiel ao que você gosta") e de uma "despretensiosa sofisticação". ${ }^{17}$ Vê-se, ainda, que a defesa "de uma decoração plural, sem certo ou errado" que a revista Casa e Jardim se atribui também é reivindicada pela exposição que louva ambientes "sem preconceitos", o que aponta para uma padronização dessas diferentes instâncias prescritivas, a despeito da onipresente exaltação de espaços domésticos "únicos" e "com personalidade".

\footnotetext{
16 "Brasil, um dos países mais lindos do mundo. O país do futebol, do carnaval, das belezas naturais, da diversidade cultural, das diferentes formas de viver, de uma identidade heterogênea e exclusiva. Tamanha pluralidade permitiu reunir na arquitetura do nosso país uma casa pequena, um apartamento grande ou uma modesta moradia no campo. E o que estes lares têm em comum? A essência de pertencer ao povo mais feliz do planeta. Pensando nessa felicidade, a Italínea busca funcionalidade, praticidade e o conforto merecido pelos brasileiros, produzindo móveis planejados para mobiliar os diferentes lares deste imenso Brasil. E, por isso, é motivo de orgulho para os brasileiros" (Quintas et al., 2013, p. 13).

${ }^{17}$ Anuário da edição de 2019, p. 21, adquirido em observação realizada em 10/11/2019.
} 


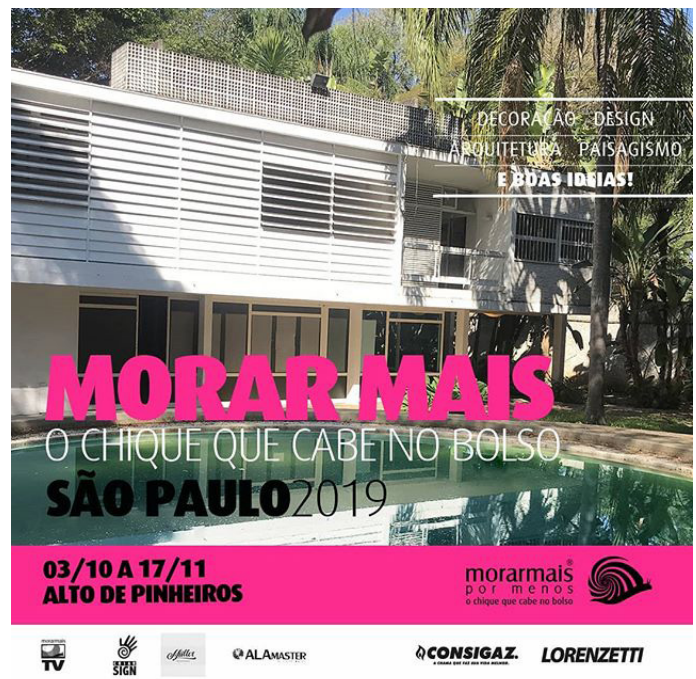

Figura 3 - Cartaz da $16^{\text {a }}$ Morar Mais, residência Ferraz de Andrade (1962) em Alto de Pinheiros, São Paulo | Fonte: Facebook Consigaz ${ }^{18}$

Ao discutir a apologia da "inesgotável singularidade" de cada indivíduo no contexto ideológico contemporâneo, Louis Pinto (2009) nota como é difícil distinguir uma prática surgida da autenticidade do eu de outra que remete a convenções impessoais (como as normas que Casa e Jardim propõe não a um morador específico, mas ao conjunto de seu público). Assim, diz o autor, a atenuação das formas mais coercitivas de autoridade não significa que os indivíduos são agora livres para fazer escolhas de que são as fontes exclusivas. Isso se vê bem nas contradições inerentes aos conselhos que insistem no abandono da ideia de uma casa para mostrar aos outros "Sem medo de ser diferente" (Quintas, 2011a, p. 11) e, a um só tempo, recomendam projetos para "impressionar" amigos e convidados; 19 preconizam "tudo o mais personalizado possível" (Quintas, 2011 b, p. 10) e, ao mesmo tempo, prescrevem que os leitores "copiem"; valorizam "o estilo de vida de cada um impresso em tudo"e, simultaneamente, bajulam os que herdam "móveis de família", 20 promovendo uma compatibilização inédita entre o fortalecimento da individualidade e das virtudes hereditárias.

\section{Elitização e "simplicidade"}

Da mesma forma que a defesa de um arranjo doméstico "pessoal" não é incompatível com a normatização do bem-morar, a celebração da "simplicidade" - outra exortação recorrente nas páginas de Casa e Jardim - acompanha a progressiva elitização do magazine. Com efeito, o exame da presença "do otimismo social das pessoas sem problemas" (Bourdieu, 2007, p. 272) mostra que as dificuldades financeiras são cada vez menos abordadas ao longo dos 15 anos cobertos pela pesquisa: se nas edições publicadas no primeiro quinquênio do período de referência abundam chamadas como "Diminua suas contas domésticas" ( $\left.n^{\circ} 542\right)$ e "Bom gosto com economia" ( $\left.n^{\circ} 559\right)$, tais manchetes se

\footnotetext{
${ }^{18}$ https://web.facebook.com/consigazbrasil/posts/1453317004792982/?_rdc=1\&_rdr(consultado em 15/04/2020). 19 "Não basta ter um lavabo. Para impressionar tem de ser 'o lavabo"'. Sumário. (2005), Casa e Jardim, $602: 6$. Sobre o hall do elevador, é dito que "tem o poder de impressionar (ou decepcionar) quem chega". Sumário. (2011), Casa e Jardim, 674: 20.

20 O livro Casas de São Paulo também enaltece residências que "abram mão de qualquer pretensão" (Barbosa e Reinés, 2009, p. 96), ao mesmo tempo em que valoriza interiores com objetos domésticos com "história e pedigree", como é o caso de um duplex nos Jardins que possui a coleção de porcelanas da família Prado ( $p$. 112).
} 
tornam mais sutis ("Imperdível: guia de 145 lojas em liquidação", n 672) e, sobretudo, menos frequentes no segundo e terceiro quinquênios, conforme observamos no gráfico 1.

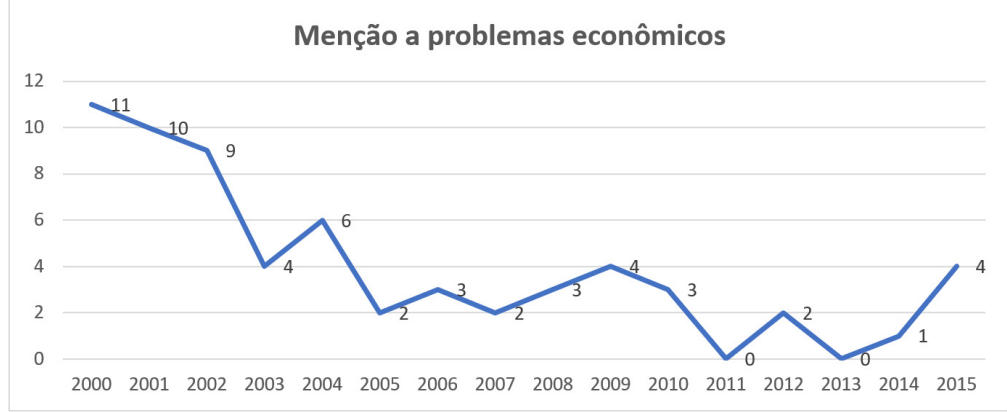

Gráfico 1 - Menções a economia | Fonte: elaboração própria com base nas chamadas das 192 capas da revista Casa e Jardim publicadas entre 2000 e 2015.

Outro indício do caráter mais "popular" da revista no início do período de referência revela-se na presença de "celebridades" na coluna "Culinária", veiculada desde 2000 e, a partir de 2001, da coluna "Casa de famoso", uma e outra, estratégias editoriais que um estudo sobre as prescrições em matéria de vinho (Garcia-Parpet, 2003, p. 192) associa às revistas que buscam atingir os leitores das classes populares. A entrevista com a diretora de redação de Casa e Jardim entre 2008 e 2016 aponta que esse momento "mais popular" do título trouxe os piores resultados: "não vendia, foi um fiasco, não vendia anúncio, não vendia em banca, porque as pessoas querem comprar um sonho". Isso teria sido um equívoco porque "você está falando de um assunto que já é para uma categoria privilegiada. Então já começa daí, nunca, nunca vai ser [popular], né?" Tanto assim que, em novembro de 2002, uma nova diretora de redação assume com a tarefa de reformular a revista. Sobre a reação dos leitores frente à exibição de residências sempre mais proibitivas, a informante avaliou que embora recebessem reclamações, respondiam que mostravam "o que havia de melhor" para que os leitores pudessem "adaptar à realidade deles". Em nome de um amor às belas coisas benéfico a todos, a revista funcionaria como uma "referência", ainda que nem todos pudessem adquiri-la: "Mas é ela que vai servir de inspiração, porque eu não vou conseguir te fornecer uma inspiração nas Casas Bahia".

A chegada de Renata Rangel como diretora de redação em fins de 2002 modifica radicalmente a fisionomia da revista. A antiga jornalista da Folha de São Paulo formada na ECA-USP imprime uma profissionalização do conteúdo discursivo que a aproxima dos critérios de apreciação das revistas de arquitetura erudita, a começar pela criação da coluna "Arquitetura", pela maior presença de arquitetos e pela menor recorrência a "celebridades", como dá a ver o gráfico 2.

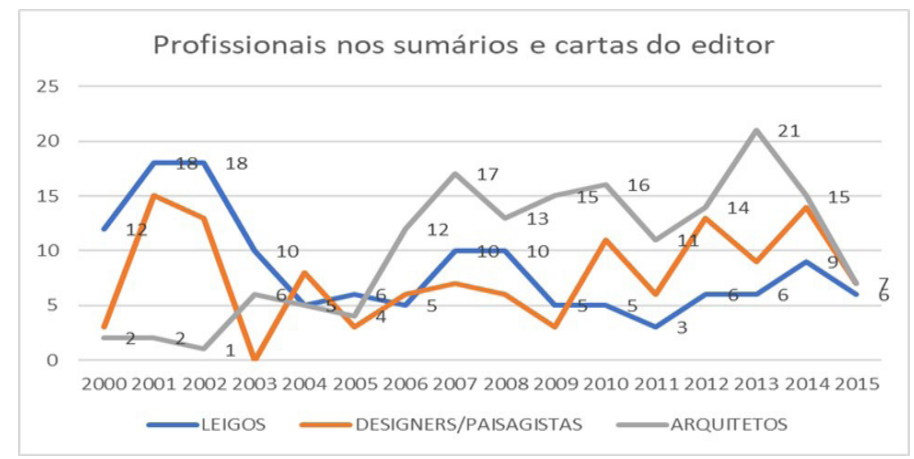

Gráfico 2 - Presença de profissionais | Fonte: elaboração própria com base nos 192 sumários e editoriais publicados pela revista Casa e Jardim entre 2000 e 2015.

Ecoando a tese de que a imprensa mais profissionalizada é também a mais dependente do mundo econômico (Duval, 2000), a presença de publicidade como fonte de financiamento 
aumenta em 85\% entre 2002 e 2007, o que é festejado em editorial (Rangel, 2008, p. 10). Nesse processo, a prescrição de gostos sempre mais cosmopolitas não é incompatível com renovadas formas de celebração da "brasilidade", as quais, por sua vez, são diretamente associadas à eleição presidencial de Luiz Inácio Lula da Silva. Intitulado "O melhor do Brasil", o exemplar de fevereiro de 2003 diz a que veio no editorial ("A cara do Brasil ") que afirma: "o Brasil olha para o Brasil. Efeito da nova fase política que se inicia" (Rangel, 2003, p. 3), anunciando matérias de "redescoberta nacional" como as que discutem uma fazenda colonial no interior paulista, uma casa de pescador em Trancoso e uma mansão modernista paulistana.

Não obstante a aparição concomitante do tema das "casas democráticas" e do adágio segundo o qual "o chique é a simplicidade", a elitização do título só faz crescer, como indica o incentivo ao colecionismo e às viagens internacionais, com exibição de casas no exterior. Assim, quando a antiga diretora de redação entrevistada assume o comando em 2008, Casa e Jardim estabiliza e prolonga essa compatibilização inédita entre a maior presença de profissionais da arquitetura doméstica e, a um só tempo, como visto, da retórica que confere mais peso ao morador. Além disso, anunciantes de luxo estão mais presentes do que nunca. ${ }^{21}$

Em estudo sobre a criação de riqueza nos países da Europa ocidental a partir do último quartel do século XX, Boltanski e Esquerre (2017) notam que a extensão da visibilidade de produtos de luxo foi estimulada pela unificação dos mercados, impulsionada pelo crescimento do número de ricos em escala mundial. Essa visibilidade crescente também se deve à crise econômica da imprensa que permitiu que a indústria do luxo assumisse sua manutenção financeira - sobretudo a da imprensa feminina, a da imprensa profissional e a dos cadernos sobre "l'art de vivre" -, em troca de uma maior indistinção entre publicidade de artigos de luxo e conteúdo redacional. Nesse contexto, a maior visibilidade de objetos cujo preço é muito elevado figura nas regiões centrais de grandes metrópoles, em vilarejos restaurados ou tombados e na mídia impressa voltada a um público leitor que, mesmo privilegiado, não o é o bastante, em média, para adquirir os produtos exibidos não apenas nas páginas publicitárias. Como afirmam Boltanski e Esquerre (2017, p. 65), "se a economia do enriquecimento visa principalmente os ricos e os muito ricos, uma de suas especificidades é abordar também os outros como se fossem ricos ou, no mínimo, mais ricos do que são".

Diante da maior propagação de produtos de luxo sem a correspondente universalização dos meios de seu desfrute, pode-se supor que a louvação da "simplicidade" se tornou onipresente em revistas que disputam a definição dominante do bem-viver (não apenas no Brasil) devido à necessidade de satisfazer as normas contemporâneas que condenam o esnobismo explícito (Johnston e Baumann, 2007, p. 192). No caso de Casa e Jardim, a recorrência de fórmulas do tipo "a simplicidade é a mais franca forma de sofisticação"é condizente com o fato de que o adjetivo "simples" é o quarto mais frequente em todas as capas publicadas entre 2000 e 2015, conforme tabela 4

TABELA 4 - Contagem frequencial dos adjetivos citados nas 192 capas

\begin{tabular}{c|c|c}
\hline Colocação & Adjetivo & Frequência \\
\hline $1^{\circ}$ & linda & 35 \\
\hline $2^{\circ}$ & moderna & 29 \\
\hline $3^{\circ}$ & pequena & 24 \\
\hline $4^{\circ}$ & simples, natural & 15 \\
\hline $5^{\circ}$ & gostosa & 14 \\
\hline $6^{\circ}$ & prática, colorida & 13 \\
\hline $7^{\circ}$ & chique & 12 \\
\hline $8^{\circ}$ & verde, acolhedora & 11 \\
\hline $9^{\circ}$ & rústica & 10 \\
\hline $10^{\circ}$ & original, brasileira, romântica, barata & 9 \\
\hline
\end{tabular}

Fonte: elaboração própria com base nas chamadas das 192 capas da revista Casa e Jardim publicadas entre 2000 e 2015

\footnotetext{
${ }^{21}$ Em 2000, as páginas publicitárias ocupavam 19\% da revista (22 páginas de um total de 116), ao passo que em 2010 a porcentagem sobe para 25\%, com 37 das 148 páginas dedicadas a anunciantes de maior luxo.
} 
Mas, se o sumário do n 603 atribui à "simplicidade" a maior audácia de uma casa de vidro, alumínio e madeira que flutua sobre as águas de Kalmar, na costa da Suécia e o sumário do n 691 fala da "simplicidade" dos pisos e paredes de pinus natural de uma casa de três andares no litoral da África do Sul (tida como exemplo de "despojamento total"), então é porque "simples" é uma construção social, e não algo relacionado às propriedades intrínsecas das casas apresentadas. $O$ mesmo pode ser dito do sumário do $n^{\circ} 672$, que glorifica uma casa na ilha de Formentera, na Espanha, que supostamente estaria "longe da ostentação", quando se trata de "um refúgio de férias com direito a cama embaixo da árvore e lavanda no lugar de grama". Ou então do sumário do n 718, cuja matéria "Só o necessário"(cujo cabeçalho afirma que "é possíve/ viver bem na simplicidade") é ilustrada pela imagem de uma residência modernista feita de "materiais brutos e formas puras", quando se sabe que essa arquitetura - igualmente evocada pelos adjetivos "natural" e "rústica", que também integram a lista dos dez mais citados - exige, muito pelo contrário, matéria-prima e mão-de-obra mais sofistica das (Durand, 1989; Rosatti, 2016). Não obstante os espaços domésticos excepcionais anunciados no sumário do n 672 - como a casa de $800 \mathrm{~m}^{2}$ em Trancoso "a dois passos da praia" -, o editorial do mesmo exemplar insistirá na superioridade da casa que resgata as coisas simples da vida, honrando "valores como simplicidade, consumo consciente e memória afetiva"(Quintas, 2011c, p. 8).

Nessa linha de juízo, o editorial do n 645 refere-se à matéria "Viver com simplicidade" - estampada na chamada da capa "Simplicidade é um luxo" - para pontificar que hoje as expectativas quanto à casa "tendem a se voltar mais para o emocional do que para a ostentação", e que "nos dias de hoje o que importa é você amar o seu espaço, sentir-se aconchegado nele, independente do que os outros vão achar" (Quintas, 2008b, p. 10). O suposto de que a sociedade contemporânea buscaria "menos luxo, mais aconchego" figura na capa do $n^{\circ} 700$, como se nota no sumário que anuncia a reportagem "Morar bem é simples". Vê-se, desse modo, que a despeito das condições de existência cada vez mais privilegiadas subentendidas na aquisição dos espaços residenciais efetivamente mostrados, o editorial evocará elementos afetivos para definir o bem-morar. Desse modo, enquanto o sumário do exemplar de julho de 2010 anuncia reportagens que mostrarão uma reforma modernista numa residência de $500 \mathrm{~m}^{2}$ no bairro paulistano dos Jardins e uma casa de campo de pedra "rústica" e "sem excessos" na Toscana ("Simplicidade na Toscana"), a carta da diretora de redação sequer mencionará ambas as casas, optando por enfatizar que a casa que traz felicidade "não necessariamente tem a ver com grandes gastos ou obras"(Quintas, 2010c, p. 8) mas, sim, com fotografias de família, "uma plantinha" e um bicho de estimação, por exemplo. Enquanto o editorial do n 646 louva os "projetos nada pretensiosos"(Quintas, 2008c, p. 10), o sumário do mesmo exemplar apresenta a casa de $670 \mathrm{~m}^{2}$ com "delicadas marquises de concreto e uma passarela de mármore que a corta de fora a fora" (p. 13). Outra não é a análise que pode ser feita do número 689, pois embora o sumário anuncie uma casa modernista de $300 \mathrm{~m}^{2}$ - de vidro sustentável projetada pelo célebre escritório de arquitetura MMBB -, uma casa "rústica" do início do século XX em Barcelona com peças de design que a mantêm atual e, ainda, "casas fora do comum" em São Paulo, Rio de Janeiro e Goiânia, o editorial reverenciará o partido de mostrar "casas de verdade", "sem regras" e com o que haveria de mais precioso: família, bichos, plantas e histórias (Quintas, 2012a, p. 12). A temática do "simples e luxuoso"aparece nas capas e sumários dos números 633 e 651, mas é no editorial do n 684 ("Um luxo") que mais se insistirá no argumento de que o luxo é a simplicidade e de que "a melhor casa do mundo é, sem dúvida, a que tem cheirinho de bolo assando"(Quintas, 2012b, p. 8) e, não, arquitetura elaborada, móveis luxuosos e tecnologia de última geração.

A necessidade de resolver a "tensão entre uma ideologia inclusiva de consumo cultural democrático, de um lado, e uma ideologia excludente de gosto e distinção, de outro" (Johnston e Baumann, 2007, p. 165) dá-se exemplarmente a ver no editorial "Decore sem crise" (Quintas, 2009d, p. 8). Ao discutir a reclamação de leitores quanto ao preço 
dos produtos mostrados, a diretora de redação orienta os que não podem comprar as sugestões da revista a tomá-las como uma "referência" para "customizar" um móvel a ser confeccionado por um marceneiro. Mas ao exemplificar essa recomendação acaba-se por aconselhar os leitores a "adquirir móveis que possuam poder de revenda", ou seja, aqueles assinados pelos "designers nacionais mais bem cotados para se investir". Outro indicador de como está implícita a valorização do que é socialmente discriminante figura no sumário do n 661 (p. 8): "para criar um ambiente infantil realmente bacana, não basta imitar o mundo adulto e diminuir as medidas dos móveis. Designers de renome lançam peças consagradas e criativas especialmente para o mundo mirim". Mas, também neste caso, a revista lançará mão de estratégias discursivas que não se reduzem a prescrever o que é bastante exclusivo. Assim, o editorial do exemplar em pauta ('Pense e aja verde") compensará a matéria "Design para menores" (anunciada na capa) centrando foco na importância da consciência ecológica. Ainda que, aí também, se prescreva gostos que não estão ao alcance da maioria (como os móveis de madeira de origem sustentável comprovada), o tom edificante segue no sentido de recomendar aos leitores "repensar suas escolhas de consumo", numa referência explícita a valores que todos estão em condições de homenagear (Quintas, 2010d).

O partido de enfatizar aspectos mais convincentes moralmente não significa, contudo, que a capacidade de conceber espaços domésticos "chiques" tenha deixado de ser um critério de excelência humana reverenciado, como revela o fato de que o adjetivo "chique" também está entre os 10 mais frequentes no conjunto das capas publicadas. Além disso, as detestações culturais subentendidas nos preceitos repertoriados permitem antever os portadores potenciais das escolhas que não condizem com a "justa" apreciação arquitetônica. Mirando os "excessos" implicitamente atribuídos aos recém-enriquecidos, Casa e Jardim sentencia que "vigoram cada vez mais a simplicidade, a mistura de estilos, as boas peças assinadas, [e que] saem definitivamente a ostentação, o estilo neoclássico" (Rangel, 2006, p. 4), como se a posse de peças de designers de renome pudesse, sem paradoxo, ser considerado algo "simples". Tais paradoxos são tanto mais evidentes quanto mais tivermos em vista que a revista Casa e Jardim não apenas detrata reiteradamente o que julga ser a "ostentação" associada ao gosto "neoclássico"22 - que carrega "a pecha da ignorância e do 'novo-riquismo" (Barbosa e Reinés, 2009, p. 20)-, como reverencia casas que exibem peças e móveis "de família", uma e outra, maneiras de enaltecer a antiguidade do pertencimento às elites brasileiras.

\section{Conclusão: moderação da ostentação?}

A conciliação com algumas das mais antigas das distinções sociais não impediu que a revista prescrevesse e, mesmo, exaltasse, em diversos exemplares, certos gostos automaticamente associados às classes populares, como as cores vibrantes e o artesanato. Poder-se-ia pensar que, levado às últimas consequências, o populismo cultural de que estão imbuídas as incontáveis críticas do tipo "casa ao seu modo" aniquilaria a própria razão de ser de formadores do gosto como Casa e Jardim. No entanto, a análise do conteúdo das estratégias discursivas passadas em revista escancara, antes, a novidade que consiste precisamente em continuar a prescrever, mas sob uma aparência não-prescritiva. Por meio dessa prescrição que não se assume enquanto tal é que a revista consegue não se render, como visto, à perspectiva unilateral de dois elementos até então incompatíveis, a saber: a recorrência sistemática aos especialistas da arquitetura doméstica e, a um só tempo, ao ramerrão que consiste em outorgar uma importância inaudita ao gosto dos moradores.

22 Sobre a associação entre prédios "neoclássicos" e moradores recém-enriquecidos ver Pulici $(2014,2015)$. 
Assim, muito embora as onipresentes declarações de que "na decoração, tudo pode" (Quintas, 2010e, p. 6) e de que se deve aderir aos referenciais da "simplicidade" e da fidelidade ao gosto do morador, as diferentes preferências domésticas não são igualmente apreciadas nesse guia do bem-morar. Com efeito, uma matéria dedicada ao que é in e out em matéria de decoração nota que a sanca, ornamentação recorrente nos interiores das casas construídas no âmbito do programa Minha Casa Minha Vida (Ishiki, 2017), "está por fora"(n 619, 2006, p. 40). Considerado out é também a "cópia de móvel, CD, objeto, relógio, seja lá o que for" (o que é reiterado na matéria "Viva o original", que detrata a compra de cópias e adverte que "Design assinado tem de ser legítimo"). ${ }^{23}$ Intitulada "Ao natural", a matéria que condena a sanca e a cópia de design assinado também apresenta a edificação "neoclássica" da antiga Daslu como gosto a ser esconjurado (out). Mas a associação persistente dos prédios "neoclássicos" ao esnobismo antiquado que lhe seria inerente acaba por ocultar o grande privilégio subentendido na aquisição de casas modernistas (Rosatti, 2018) e/ou ecológicas, em que tudo figura em estado "natural" (exigindo, por isso mesmo, mão-de-obra e materiais de mais alta qualidade). Os adjetivos "moderno", "natural", "verde" e "rústico" são, aliás, o segundo, o quarto, o oitavo e o nono mais citados nas chamadas das capas, tal como "modernista" (30,3\%), "rústico" (11,8\%) e "ecológico" (8\%) figuram como o primeiro, o terceiro e o quinto "estilos" mais recorrentes nos editoriais e sumários, no mais das vezes, para se referir a algo bastante sofisticado, como o uso de madeira maciça, certificada, em estado bruto, "com os veios e imperfeições à mostra", como precisa o editorial do número 620. Ainda assim, o sumário e o editorial do número 624 reverenciam uma cobertura carioca "moderníssima" por supostamente repudiar "os excessos", quando a posse de uma cobertura modernista de $400 \mathrm{~m}^{2} \mathrm{com}$ vista para o Pão-de-Açúcar e peças de grife é, precisamente, algo que em tudo "excede" aos padrões normais. $\bigcirc$ mesmo pode ser dito da reportagem "O topo e nada mais": apresentada no sumário do número 625, uma mansão modernista de $478 \mathrm{~m}^{2}$, construída no ponto mais alto de uma montanha na cidade de Ilhabela, figura como modelo de um jeito "rústico" de morar.

Vê-se, desse modo, que os princípios preconizados pela crítica de arquitetura para definir opções residenciais legítimas somente num certo sentido distanciam-se das prescrições que outrora recomendavam a adesão incondicional ao morar "burguês". Filiando-se aos climas de opinião do momento, que recompensam a depreciação das casas que se supõe rendidas à exibição da opulência econômica, os conselhos inventariados de fato fazem emergir um público que deve ser amestrado de modo a desenvolver aspirações progressistas em matéria de arquitetura doméstica, como revela a defesa de uma nova função para os quartos de empregada "mais parecidos com cativeiros" 24 . Mas, o que parece tão somente validar a "casa democrática" - para usar as categorias nativas - sanciona, em verdade, novas competências socialmente discriminantes.

Em vista disso é que se pode concluir que os posicionamentos estéticos e ideológicos passados em revista não fazem apenas esconjurar um passado marcado pelo maior dirigismo do gosto, e menos ainda invalidar as hierarquias em matéria de arquitetura e decoração. Ao contrário, as regularidades temáticas identificadas nas prescrições veiculadas nos primeiros 15 anos do século XXI apontam para a legitimidade sempre renovada da arquitetura "modernista" - eterno antídoto ao morar supostamente espalhafatoso dos chamados novos-ricos - e, cada vez mais, da arquitetura "ecológica" (que se combinam

\footnotetext{
${ }^{23}$ Sumário. (2014), Casa e Jardim, 711: 17

${ }^{24}$ Sumário (2005), Casa e Jardim, 610:10. Em Casas de São Paulo, o prefácio da editora de Casa Vogue exalta a casa "sem ostentação" (p. 7) que o arquiteto Marcio Kogan projetou "sob medida" para uma amiga. A própria autora do livro descreve sua casa de modo a dar destaque à eliminação da "escada pretensiosa" (p. 96), o que não a impede de mencionar "outro velho Chesterfield, maior, couro descascando, também inglês, e que foi da biblioteca de meu pai no Rio de Janeiro".
} 
na descrição prescritiva de um sem número de projetos, como o chamado "casa do bem", uma residência de veraneio construída no litoral paulista, "de $395 \mathrm{~m}^{2}$, dotada de amplas aberturas e soluções sustentáveis"). ${ }^{25}$

Subentende-se, em todas essas profissões de virtude, que as frações "progressistas" das elites são também as portadoras potenciais das predileções mais condizentes com as definições contemporâneas da excelência residencial. Desse modo, longe de se limitar a valorizar a história do morador e os ambientes domésticos "mais despojados", os princípios de hierarquização subjacentes às "boas maneiras de morar" inventariadas sugerem que, se no passado o principal papel da casa era simbolizar as propriedades sociais de seus proprietários (Carvalho, 1996: 177), também nos dias de hoje não se deixa de "jogar com as formas arquitetônicas classificatórias para zelar por sua posição sociorresidencial" (Collet, 2015, p. 168), não obstante toda a pregação contrária à ostentação dos sinais mais óbvios da opulência doméstica.

\section{Agradecimentos}

Este texto é uma versão reformulada do paperapresentado no GT 14 - Elites, espaços e formas de dominação, coordenado por Ernesto Seidl e Irlys Barreira no âmbito do $44^{\circ}$ Encontro da Anpocs (2020). Agradeço aos coordenadores do grupo de trabalho pela oportunidade, a Eliana dos Reis pela discussão da primeira versão do paper, a Wilver Portella pela verificação das tabelas e gráficos, e aos pareceristas da RBCS e a Marcos Nobre pela leitura arguta do artigo.

\section{Bibliografia}

BARBOSA, Maria Ignez (texto); REINÉS, Tuca (fotografia). (2009), Casas de São Paulo. São Paulo, Metalivros.

BOLTANSKI, Luc; ESQUERRE, Arnaud. (2017), Enrichissement. Une critique de la marchandise. Paris, Gallimard.

BOURDIEU, Pierre. (2000), Les structures sociales de l'économie. Paris, Seuil.

BOURDIEU, Pierre. (2007), A Distinção. Crítica social do julgamento. São Paulo, Edusp; Porto Alegre, Zouk.

CAMARGOS, Márcia. (2001), Villa Kyriall. Crônica da belle époque paulistana. São Paulo, Editora Senac.

CAMPOS, Eudes. (2005), "Nos caminhos da Luz, antigos palacetes da elite paulistana". Anais do Museu Paulista, 13: 11-57.

CARVALHO, Maria Cristina Wolff de. (1996), "Bem-morar em São Paulo, 1880-1910: Ramos de Azevedo e os modelos europeus". Anais do Museu Paulista, 4: 165-200.

CARVALHO, Vânia Carneiro de. (2008), Gênero e artefato. O sistema doméstico na perspectiva da cultura material - São Paulo, 1870-1920. São Paulo, Edusp.

CHEVALIER, Sophie ; LALLEMENT, Emmanuelle; CORBILLÉ, Sophie. (2013), Paris résidence secondaire. Enquête chez ses habitants d'un nouveau genre. Paris, Éditions Belin, Éditions de la Maison des Sciences de l'Homme.

COHEN, Jean-Louis. (2004), "Promesses et impasses du populisme ». Cahiers de la recherche architecturale et urbaine, 15-16: 167-184.

${ }^{25}$ Sumário. (2012), Casa e Jardim, 684: 15. 
COLLET, Anaïs. (2015), Rester bourgeois. Les quartiers populaires, nouveaux chantiers de la distinction. Paris, La Découverte.

DENÈFLE, Sylvette; BRESSON, Sabrina; DUSSUET, Annie; ROUX, Nicole. (2006), Habiter Le Corbusier. Pratiques sociales et théorie architecturale. Rennes, PUR.

DURAND, José Carlos. (1989), Arte, privilégio e distinção. Artes plásticas, arquitetura e classe dirigente no Brasil, 1855-1985. São Paulo, Perspectiva/Edusp.

DUVAL, Julien. (2000), "Concessions et conversions à l'économie: le journalisme économique en France depuis les années 80 ». Actes de la recherche en sciences sociales, 131-132: 56-75.

FERRARI, Federico. (2015), Le populisme esthétique. L'architecture comme outil identitaire. Paris, Infolio.

GARCIA-PARPET, Marie France. (2003), « Styles de vie et manières de boire: un marché de l'offre des biens de prescription œnologique ». Cahiers lillois d'économie et de sociologie, 41-42: 177-197.

GARCIA-PARPET, Marie-France. (2004), « Le marché de l'excellence: les classements des grands crus à l'épreuve de la mondialisation ». Genèses, 56: 72-96.

GILBERT, Pierre. (2016a), "Classes, genre et styles de vie dans l'espace domestique ». Actes de la recherche en sciences sociales, 215: 4-15.

GILBERT, Pierre. (2016b), «Troubles à l'ordre privé: les classes populaires face à la cuisine ouverte ». Actes de la recherche en sciences sociales, 215: 102-119.

GUEDEZ, Annie. (2004), "La 'belle maison' dans la Grande Lande », in V. Nahoum-Grappe \& O. Vincent (orgs.), Le goût des belles choses. Ethnologie de la relation esthétique, Paris, Éditions de la MSH, pp. 49-65.

HOMEM, Maria Cecília Naclério. (1996), O palacete paulistano e outras formas urbanas de morar da elite cafeeira, 1867-1918. São Paulo, Martins Fontes.

ISHIKI, Ana Florice. (2017), O espaço residencial da "nova classe média". Preferências estéticas e práticas distintivas em um condomínio de Santo André. Dissertação de mestrado. Universidade Federal de São Paulo.

JOHNSTON, Josée; BAUMANN, Shyon. (2007), "Democracy versus Distinction: A Study of Omnivorousness in Gourmet Food Writing". American Journal of Sociology, 113: 165-204.

LAMONT, Michèle. (1992), Money, Morals and Manners. The Culture of the French and the American Upper-Middle Class. Chicago, University of Chicago Press.

LAFERTÉ, Gilles. (2016), «Ferme, pavillon ou maison de campagne: les formes résidentielles de l'embourgeoisement agricole ». Actes de la recherche en sciences sociales, 215 : 16-33.

LEMOS, Carlos. (2003), "Morar em São Paulo". Casa e Jardim, 581: 92-97.

LIZÉ, Wenceslas \& NAUDIER, Delphine \& ROUEFF, Olivier. (2011), Intermédiaires du travail artistique. À la frontière de l'art et du commerce. Paris, La Documentation française.

LOURENÇO, Ana. (2020), "Casa arrumada e renovada". O Estado de S. Paulo, 14 nov. (caderno Especial).

MIRA, Maria Celeste. (2013), O leitor e a banca de revistas. A segmentação da cultura no século XX. $3^{a}$ edição, São Paulo, Olho d'água/Fapesp.

NAULIN, Sidonie. (2017), Des mots à la bouche. Le journalisme gastronomique en France. Rennes/Tours, PUR/Presses universitaires François Rabelais.

PINÇON, Michel; PINÇON-CHARLOT, Monique. (2007), Les ghettos du Gotha. Comment la bourgeoisie défend ses espaces. Paris, Seuil.

PINTO, Louis. (2009), Le collectif et l'individuel. Considérations durkheimiennes. Paris, Raisons d'agir. 
PULICl, Carolina. (2014), "Visões do gosto arquitetônico passadista: problematizando o 'estilo neoclássico' de São Paulo em perspectiva internacional". Anais do Museu Paulista, 22: 219-248.

PULICl, Carolina. (2015), "Prédios 'neoclássicos' no espaço residencial das elites de São Paulo". Estudos avançados, 85: 237-261.

PULICI, Carolina. (2020), « Les bonnes manières d'habiter: la presse d'architecture et de décoration entre hiérarchies du marché et autorité culturelle ». Actes de la recherche en sciences sociales, 232-233: 86-105.

QUINTAS, Simone. (2008a), "Viva a diferença". Casa e Jardim, 644: 4.

QUINTAS, Simone. (2008b), "Ame sua casa". Casa e Jardim, 645: 10.

QUINTAS, Simone. (2008c), "Cor é uma delícia". Casa e Jardim, 646: 10.

QUINTAS, Simone. (2009a). "Sim, você pode (e deve)". Casa e Jardim, 651: 8.

QUINTAS, Simone. (2009b). "A sua casa é (ou deveria ser) o que você é". Casa e Jardim, 655: 8.

QUINTAS, Simone. (2009c), "Saindo do forno". Casa e Jardim, 657: 8.

QUINTAS, Simone. (2009d). "Decore sem crise". Casa e Jardim, 652: 8.

QUINTAS, Simone. (2010a), "O ano da casa linda". Casa e Jardim, 660: 8.

QUINTAS, Simone. (2010b), "Fortes emoções". Casa e Jardim, 664: 8.

QUINTAS, Simone, (2010c), "Entenda sua casa". Casa e Jardim, 666: 8.

QUINTAS, Simone, (2010d), "Pense e aja verde". Casa e Jardim, 661: 6.

QUINTAS, Simone. (2010e), "Tudo é possível". Casa e Jardim, 669: 6.

QUINTAS, Simone. (2011a), "Sem medo de ser diferente". Casa e Jardim, 676: 11.

QUINTAS, Simone. (2011 b), "Razão e (muita) sensibilidade". Casa e Jardim, 675: 10.

QUINTAS, Simone. (2011c), "Este ano eu vou". Casa e Jardim, 672: 8.

QUINTAS, Simone. (2012a), "Apaixonados por decoração". Casa e Jardim, 689: 12.

QUINTAS, Simone. (2012b), "Um luxo". Casa e Jardim, 684: 8.

QUINTAS, Simone. (2013), "Apresentação", in Quintas et al., Casas do Brasil. São Paulo, Editora Globo, p. 11.

QUINTAS, Simone; TAVARES, Daniel; DÊGELO, Marilena. (2013), Casas do Brasil (Casa e Jardim), São Paulo, Editora Globo.

RANGEL, Renata. (2003), "A cara do Brasil". Casa e Jardim, 577: 3.

RANGEL, Renata. (2006), "Felicidade em casa". Casa e Jardim, 619: 4.

RANGEL, Renata. (2008), "Até breve". Casa e Jardim, 642: 10.

REICHENBACH, Carlos. (1953), "Carta do editor". Casa e Jardim, 1: 7-6.

ROSATTI, Camila Gui. (2016), Casas burguesas e arquitetos modernos: condições sociais de produção da arquitetura paulista. Tese de doutorado. Universidade de São Paulo, São Paulo.

ROSATTI, Camila Gui. (2018), "Béton brut et raffinement du goût: la clientèle et l'économie symbolique de l'architecture d'auteur". Brésil(s). Sciences humaines et sociales, 14 (online). DOI: https://doi.org/10.4000/bresils.3826

TAPIE, Guy. (2018), La culture architecturale des Français. Paris, Presses de Sciences Po.

WOLFF, Sylvia Ferreira Santos. (2001), Jardim América: o primeiro bairro-jardim de São Paulo e sua arquitetura. São Paulo, Edusp/Fapesp/Imprensa Oficial do Estado.

WRIGHT, Gwendolyn. (1980), Moralism and the Model Home. Domestic Architecture and Cultural Conflict in Chicago 1873-1913. Chicago e Londres, University of Chicago Press. 